OPEN ACCESS

Edited by:

Xuhua Shi,

Zhejiang University, China

Reviewed by:

Lei Wu,

Zhejiang University, China Feng Cheng,

University of Nevada, Reno,

United States

*Correspondence:

Wenjun Zheng

zhengwenjun@mail.sysu.edu.cn

Specialty section:

This article was submitted to Structural Geology and Tectonics,

a section of the journal

Frontiers in Earth Science

Received: 03 January 2022

Accepted: 07 February 2022

Published: 24 February 2022

Citation:

Jia J, Zheng W, Zhang Y, Wei S, Liang S, Feng C, Zhu Y, Tang $Q$ and Wang W (2022) Tectonic Deformation of an Intraplate Orogenic Belt: Mesozoic Sedimentary Basins in the

Northeastern Qilian Shan, China.

Front. Earth Sci. 10:847921.

doi: 10.3389/feart.2022.847921

\section{Tectonic Deformation of an Intraplate Orogenic Belt: Mesozoic Sedimentary Basins in the Northeastern Qilian Shan, China}

\author{
Jiabao Jia ${ }^{1,2}$, Wenjun Zheng ${ }^{1,2 *}$, Yipeng Zhang ${ }^{1,2}$, Shiqi Wei ${ }^{1,2}$, Shumin Liang ${ }^{1,2}$, \\ Changhuan Feng ${ }^{1,2}$, Yu Zhu ${ }^{1,2}$, Qing Tang ${ }^{1,2}$ and Weitao Wang ${ }^{1,2}$
}

${ }^{1}$ Guangdong Provincial Key Laboratory of Geodynamics and Geohazards, School of Earth Sciences and Engineering, Sun Yatsen University, Guangzhou, China, ${ }^{2}$ Southern Marine Science and Engineering Guangdong Laboratory (Zhuhai), Zhuhai, China

The Qilian Shan, located in the northeastern Tibetan Plateau, is an intraplate orogenic belt that underwent several episodes of fold and thrust deformation, particularly during the Mesozoic and Cenozoic. However, the deformation styles and relationships between the basin and mountains remain controversial. Therefore, in the current study, we conducted detailed field mapping of the sedimentary basins in Sunan and Huangcheng, and observed three episodes of compressive tectonic activity. We also restored a deformed section to determine the shortening rate of the Cretaceous sedimentary Sunan Basin. The first thrust episode, during the Paleogene, involved a southwestward thrust motion, comprising the Yumu Shan and Gaizhangdaban thrust systems. The second Neogene episode involved the northeastern thrust belt in the northern Qilian Shan, which comprises the Northern Qilian thrust system. The third episode produced NW-trending strike-slip activity that became the major tectonic deformation style; thus, the entire block rotated clockwise. Additionally, the restored section revealed that the Cretaceous strata have been shortened by $\sim 3.56 \%$. Collectively, these results indicate that the Sunan and Huangcheng area on the northeastern Tibetan Plateau is influenced by the far-field effects of the collision between the Indian and Asian continents, as well as the effects of intraplate orogenic processes related to the collision of the Alashan Block and the Qilian Shan. Therefore, the current study has defined the deformation style in the northeastern Qilian Shan region, so we wish to give a clarification of the tectonic evolution and forecast the tectonic propagation in the Qilian Shan region.

Keywords: tectonic deformation style, thrust system, intraplate orogenesis, deformation model, orogenic topography

\section{INTRODUCTION}

The Tibetan Plateau is a region with a complex tectonic deformation history. Before the Late Cretaceous, the deformation style of the Qilian Block was a multiple-accretionary orogenic belt (Xiao et al., 2009), while the northern Tibetan Plateau underwent two phases of extensional deformation that were not transmitted to northern Qilian Shan (Chen et al., 2003). Additionally, two phases of continental collision occurred in the central Qilian Shan before the Cretaceous (Zuza et al., 2019). It is believed that the northern Qilian Shan region formed higher topography than the central Qilian 
Shan region during the Mesozoic (Wang et al., 2021). Moreover, based on reports from the Bureau of Mineral Resources of Gansu Province (BMRGP, Regional Geological Survey) (1982), Bureau of Mineral Resources of Inner Mongolia Province (BMRIMP, Regional Geological Survey) (1991) and Bureau of Mineral Resources of Qinghai Province (BMRQP, Regional Geological Survey) (1991), it is clear that the data pertaining to the geometry of the faults and strata constitute the geological background, while the relationships between the faults and folds remains unclear. To address this gap in knowledge, we began performing detailed map fielding to characterize the tectonic activities responsible for causing the specific strata and fault geometry. Although an uplift event was identified during the Late Cretaceous in the eastern Qilian Shan (Pan et al., 2013), and a slow and continuous cooling period was observed in the Eastern Qinghai Nan Shan (Jolivet et al., 2001; Lin et al., 2021), it remains unclear whether the Sunan Basin and Huangcheng Basin in northeastern Tibet formed during this period.

Previous studies have focused on the uplift of the Tibetan Plateau following collision of the Indian plate with the Eurasian plate (Zhong and Ding, 1996), which is thought to have begun from 60 to $55 \mathrm{Ma}$ (Zuza et al., 2018a, 2018b). Moreover, based on the trench sediments in the west Himalaya, the orogeny likely began at the middle Paleocene ( $\mathrm{Hu}$ et al., 2015). Although the entire plateau has continued to grow owing to this collision (Yin, 2006; Yuan et al., 2013), another view states that the timing of the Qilian Shan deformation coincided with the collision of the IndoEurasian (Yin et al., 2008a, 2008b; Dayem et al., 2009; Clark et al., 2010; He et al., 2021). Moreover, the eastern Kunlun Shan is thought to be serve as the roots when the strike-slip event occurs (Cheng et al., 2021). Meanwhile, on the northeastern Tibetan Plateau, the tectonic blocks underwent shear, extrusion, and rotation from the Mesozoic to the Cenozoic during the Late Jurassic to Cretaceous (Cheng et al., 2019b).

The Qilian Shan fold and thrust system records the effects of changes in the deformation style of the Indian and Eurasian blocks during the Cenozoic. That is, the deformation patterns within the strata are well preserved and capable of reflecting the evolution of the Qaidam Basin, which is in the western Qilian Shan (Cheng et al., 2021). However, the tectonic deformation style present during the Cretaceous in the Sunan Basin and Huangcheng Basin remains poorly understood. To investigate the older topography, it is necessary to determine the deformation architecture of the Late Cretaceous strata. Thus, in the current study, based on the divisions of the tectonic belt and the sedimentary background (BMRGP, 1982; Zhou et al., 2002; Dai et al., 2006; Jin et al., 2010; Wang et al., 2017), we selected two typical areas in the northeast Qilian Shan region, namely, the Sunan, and Huangcheng basins, for further analysis. Both areas share the deformation style of a fold-thrust system.

Above all, the tectonic evolution in the northern Tibetan Plateau remains unclear, with the tectonic deformation style in the northeastern Qilian Shan during the Late cretaceous currently unknown. In this study, we focused on the period preceding the Indo-Eurasian collision and addressed the fault planes and faultrelated folds using field work and field mapping to investigate fold deformation in the study area. The aim of this study is to characterize the tectonic deformation architecture of the basin and to determine a tectonic evolutionary model for the Sunan Basin.

\section{GEOLOGIC SETTING}

The Qilian Shan is located on the northeastern margin of the Tibetan Plateau and controls the propagation of the northeastern Tibetan Plateau with an NW-trending fold and thrust system (Zhang et al., 2004; Wang et al., 2014). The northeastern Qilian Shan is bounded by the Alashan Block to the north, the Ordos Block to the northeast, and the Kunlun-Qiangtang Block to the south (Figure 1). The Qilian Shan-Hexi corridor experienced a collision between the Alashan Block and the Songpan-Ganzi Block of the Tibetan Plateau. The northeast Qilian Shan is located on the northern margin of the Nan Shan-Qilian Shan deformation belt.

In the study area, the sedimentary basin, which is covered by $1.5-2 \mathrm{~km}$ of thick Cretaceous sandstones, conglomerates, and siltstones, unconformably overlies Paleozoic sandstones and conglomerates. The Cretaceous strata, which are covered by Neogene strata, are located in the Sunan, northern Huangcheng, and Longshou Shan areas. The Cretaceous strata in the Sunan area differ from those in the Huangcheng area. According to geological mapping surveys (BMRGP, 1982), the Cretaceous strata include the Xinminpu Formation $\left(\mathrm{K}_{1} x n\right)$ in the Sunan area, while the Hekou Formation $\left(\mathrm{K}_{1} h k\right)$ is found in the Huangcheng area. The Malianggou Formation $\left(\mathrm{K}_{2} m l\right)$ is also exposed in the Huangcheng area, characterized by sandstones and conglomerates that are more well-cemented than those in the Neogene strata.

The Neogene strata are horizontally trending sandstones and conglomerates that unconformably overlie the Cretaceous strata. The Neogene strata unconformably cover the Cretaceous strata in both study areas along the southern Yumu Shan and in the southern Gaizhangdaban area. Along the Northern Qilian thrust system, Neogene strata are exposed primarily in the Yumen, Sunan, Jiuquan, and southern Gaizhangdaban areas (Figure 1). Based on data from the BMRGP (1982), the Neogene strata include the Houshaogou $\left(\mathrm{E}_{1-2} h\right)$, Baiyanghe $\left(\mathrm{E}_{3} b\right)$, and Shulehe (Ns) formations, which are characterized by red to red-brown sandstones and conglomerates. The characteristics of the Neogene deformation style include the growth strata that developed along the fault systems around the basin.

The Sunan Basin is bounded by thrust systems on the north, south, and east sides, which form elevated topography around the basin. From north to south, the major thrust faults and their associated tectonic deformation are the Yumu Shan thrust system (YMT), and the Northern Qilian thrust system (NQT). Yang (2007) found that the YMT is a regional thrust system, while the NQT is a northward thrusting system that comprises Cambrian and Ordovician klippes. On the northern and southern margins of the Sunan Basin, lightly metamorphosed limestones are thrust up against the Cretaceous basin on the hanging wall of the fault. The eastern side of the basin is bounded by metamorphosed Ordovician strata. 


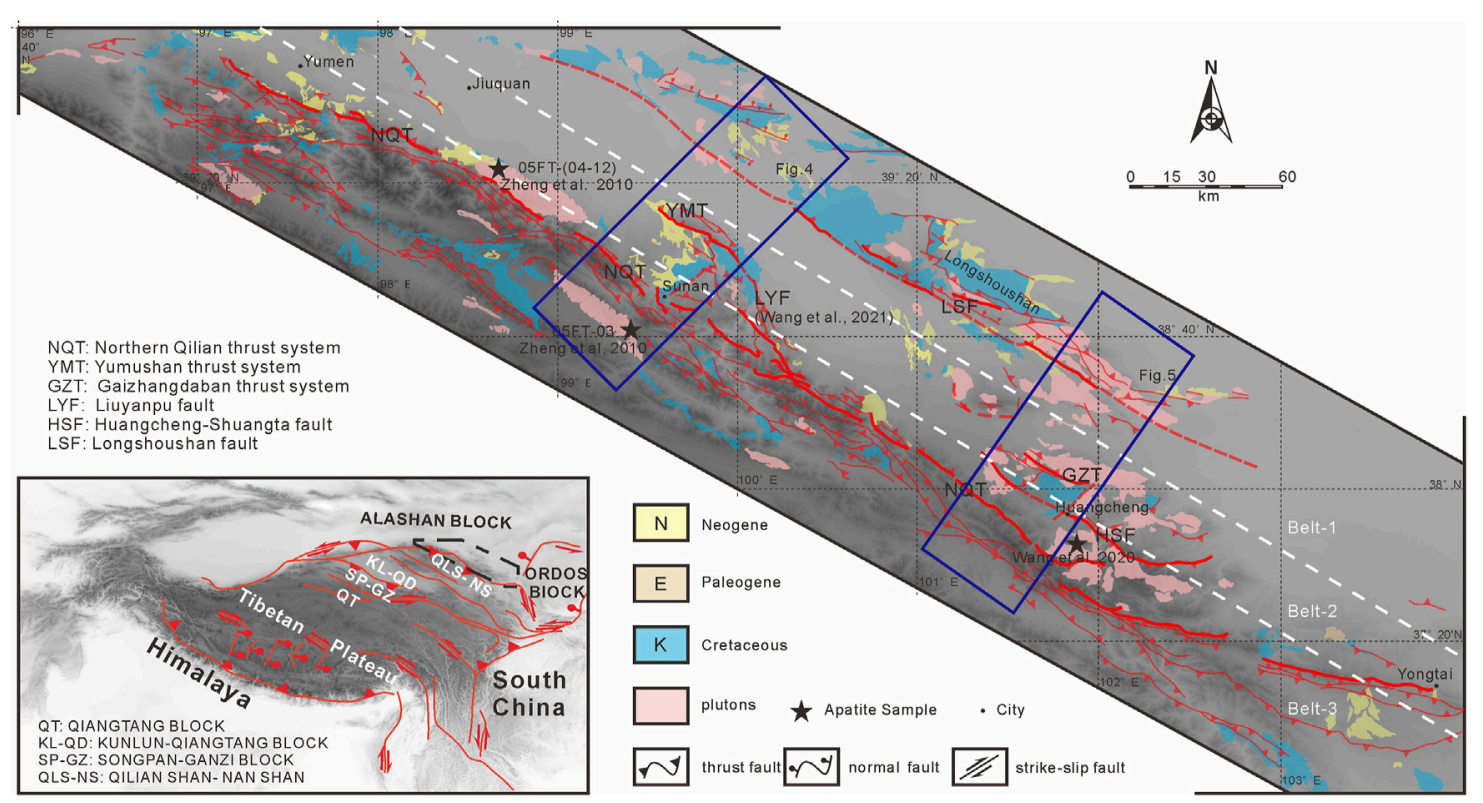

FIGURE 1 | Geologic map of the Qilian Shan-Hexi corridor. Map based on data from the Bureau of Mineral Resources of Gansu Province (BMRGP, Regional Geological Survey) (1982), BMRIMP (1991), Bureau of Mineral Resources of Qinghai Province (BMRQP, Regional Geological Survey) (1991), and fieldwork conducted for this study.

\section{ACQUISITION OF DATA AND THE ESTABLISHMENT OF DEFORMATION LAYERS}

We first collected 20 field maps (scale 1:200,000) to summarize the geometric characteristics of the fault system and the location of the target strata. We then generated detailed field work, including images that were meant to depict the relationships between the fold and thrust. Moreover, to define the kinematic characteristics, we selected the clean fault planes to accumulate the plunge data of the scratch to demonstrate the strain field. Upon completion of the field work, we reconstructed the geological mapping based on our observations and adjusted the geometry of the faults and folds.

Based on the field surveys and mapping, we defined three fault-fold deformation belts in the Qilian Shan-Hexi corridor deformation zone. The first belt (belt-1) in the north is the deformation zone closer to the Alashan terrane, where the Longshou Shan and Heli Shan are the central aspects of the Alashan orogenic belt. This belt is thought to be controlled by the Longshou Shan fault (LSF), which thrusts southwestward toward the Tibetan Plateau. In the northern part of belt-1, the Alashan terrane is weakly deformed and the crust is more stable. The second belt (belt-2) includes the Yumu Shan and Gaizhangdaban areas, both of which exhibit the same tectonic activities as in the adjacent Alashan Block and along the southern margin of the Alashan terrane thrust system. This region is controlled by both the Alashan Block and the Qilian Shan orogenic belt, forming southwestward thrusting faults and active northward faults along the northern margin of the Yumu Shan and Gaizhangdaban areas. The third deformation belt (belt-3) is the northern Qilian Shan thrust fault system, which is thought to be the edge of the
Qilian Shan-Nan Shan thrust system that is affected by the propagation of the northeastern Tibetan Plateau.

Therefore, to study the deformation history more clearly, we divided the strata into three structure deformation layers (SDLs) according to the contact relationships between each stratum (Figure 2). The first SDL is Permian-Jurassic (SDL-1), which we defined as the basement sediment. The second SDL is the Cretaceous, which comprises the major strata in the basin as footwall, is dominated by folds topping to the central basin that cause a portion of the shortening. This SDL (SDL-2) differs in the two study areas. The Cretaceous strata in both study areas are unconformably overlain by Neogene strata (SDL-3). SDL-3 is Eogene-Neogene, which includes tectonic deformation caused by the active fault system, and is gently dipping (Figure 3).

After concluding that the strata occurrence data was insufficient, we selected a cross-section of the basin from northeast to southwest, and accumulated detailed data regarding strata trends and dips, including specific altitude, longitude data, and latitude data. Based on the data strata, we used line balancing to simulate each fold hinge of the Cretaceous strata in the Sunan Basin to restore the section across the Sunan Basin. To ensure that the area of the Cretaceous strata was consistent (Elliott, 1983), we altered the thickness of the strata to fit current day measurements.

The detailed mapping allowed us to perform detailed statistical analysis of the poles for each strata occurrence, and simulate the most proximate fold hinge using the stereographic projection to show the geometry of the fold hinge, which depicted the strain orientation. Finally, based on the geological background generated by predecessors, as well as our current field work, we simulated a tectonic propagation model to represent the evolution history of the Sunan Basin. 


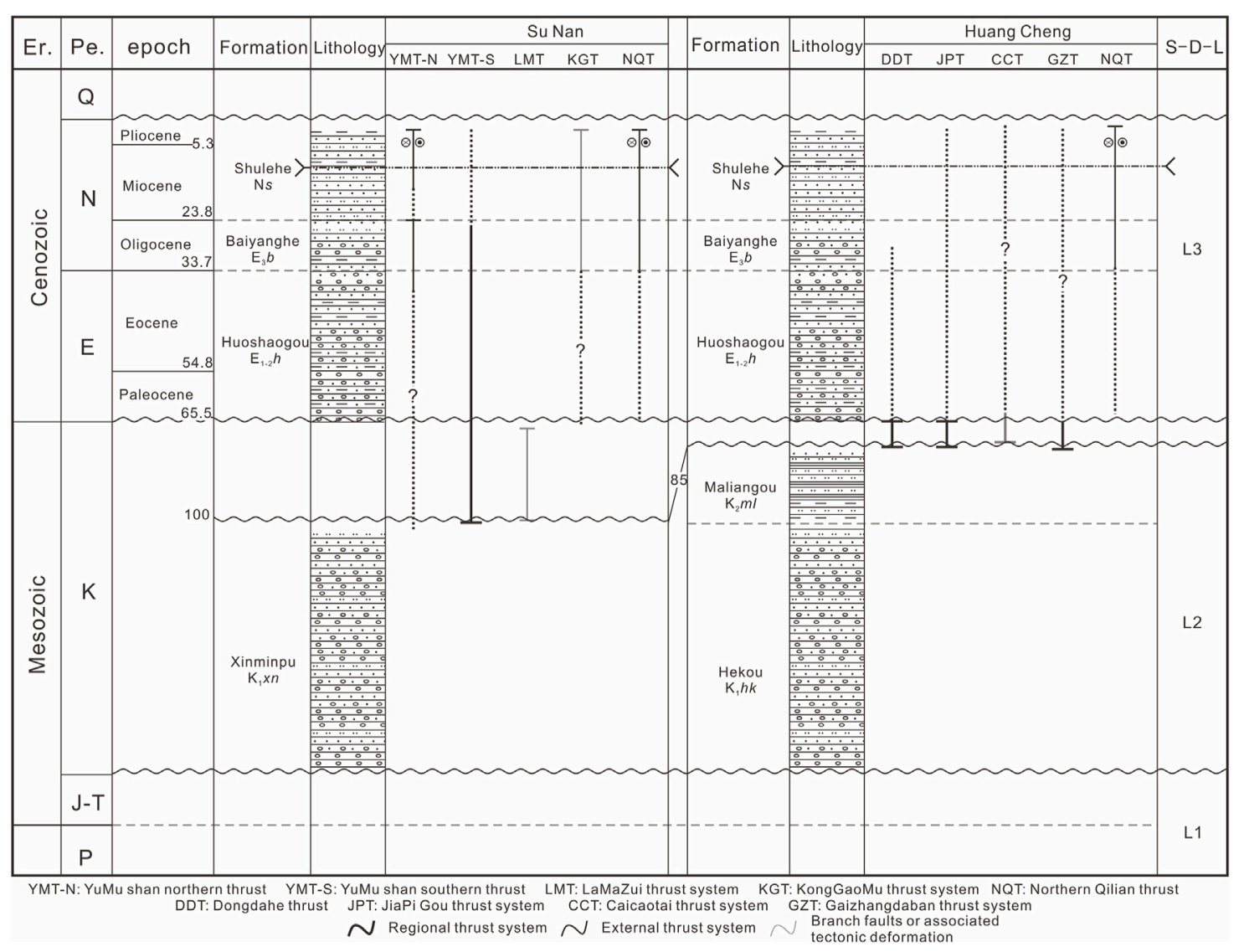

FIGURE 2 | Chronology of thrust faulting and sequence stratigraphy in Sunan and Huangcheng. Lithologic age constraints were obtained from the Bureau of Mineral Resources of Gansu Province (BMRGP, Regional Geological Survey) (1982). The time of faulting are based on the faults, strata and unconformity contacting relations from the geological map (Bureau of Mineral Resources of Gansu Province (BMRGP, Regional Geological Survey), 1982; BMRIMP, 1991; Bureau of Mineral Resources of Qinghai Province (BMRQP, Regional Geological Survey), 1991) and the field observation.

\section{IDENTIFICATION OF MAJOR TECTONIC COMPONENTS}

Deformation of the Cretaceous strata and the NW-SE thrust systems between the Paleozoic and Mesozoic control the shape of the basin, record far-field deformation influenced by the collision between the Indian and Asian plates, and can be used to determine the shortening of the northeastern Tibetan Plateau.

In the Sunan Basin, prominent tectonic structures include NW-trending thrust faults and folds. The Sunan Basin is dustpan shaped and consists of Permian-Cretaceous fold deformation and Neogene strata. The older strata are generally exposed along the northern and eastern margins of the basin, which is believed to be a basin formed by the thrust system as its footwall. The fold deformation present along the northern and southern margins of the basin manifests as folds topping to the central basin in the Cretaceous strata, which are more severely deformed around the YMT and NQT, however, are less deformed toward the center of the Sunan Basin.

The Yumu Shan Fault is located adjacent to the southern and northern margins of the Sunan Basin. The southern Yumu Shan Fault (YMT-S) is $\sim 35 \mathrm{~km}$ long and cuts through Neogene,
Cretaceous, Permian, and Silurian strata. The southern portion of the YMT-S is a Cretaceous and Neogene sedimentary basin. Along the YMT-S, the northern part of the Silurian metamorphosed mudstones has been thrust southward over Permian strata. The northern Yumu Shan Fault (YMS-N) is $\sim 40 \mathrm{~km}$ long and is located along the northern margin of the Yumu Shan, which is likely affected by the propagation of the Tibetan Plateau and is rotated clockwise. The current fault dip angle is $65^{\circ}-70^{\circ}$ (BMRGP, 1982), while the dip angle is $\sim 45^{\circ}$ in the adjacent areas of the Yumu Shan. Along the YMT-N, Silurian, Carboniferous, and Devonian strata have been thrust northward toward the Jiuquan Basin (Yang, 2007), which comprises Quaternary sediments. However, the deformation style of the Yumu Shan remains unclear. It has been proposed that the Yumu Shan klippes were derived from the nappe system of the NQT (Wang et al., 2021); however, we postulate that the Yumu Shan was controlled by the YMT-S to form the southward thrust system, thereby leaving the LMK in the basin.

In the Huangcheng Basin, regional tectonics are controlled by the Gaizhangdaban thrust system (GZT) and the Caicaotai thrust system (CCT; Figure 5). The Huangcheng Basin consists of SDL2 , and the deformation primarily comprise folds topping to the 

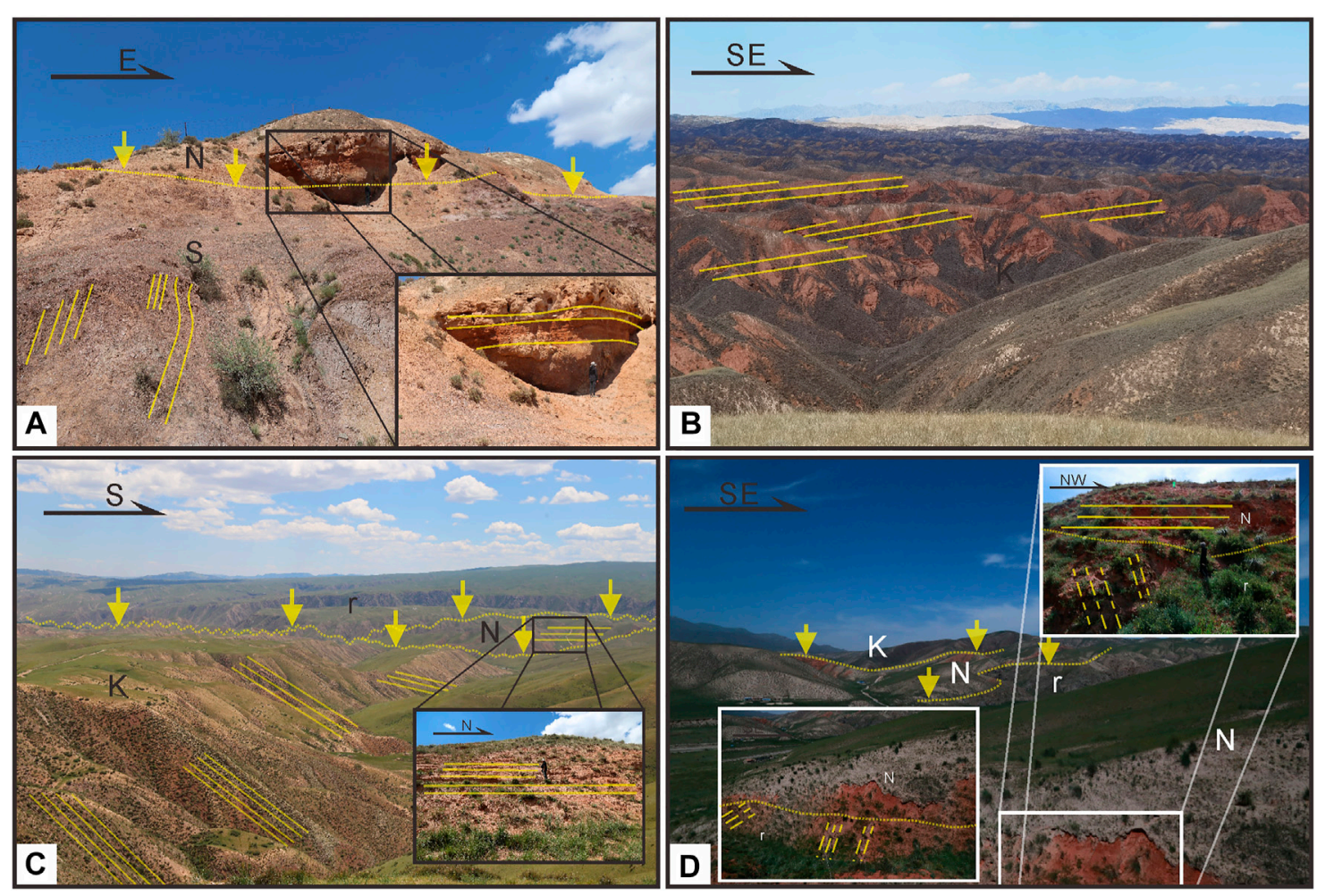

FIGURE $\mathbf{3}$ | Field photos of stratigraphic relationships in the study area. Yellow lines mean bedding. (Figure $\mathbf{4}$ and Figure $\mathbf{5}$ for regional location of this map). (A) Strata of the Lamazui klippe. Neogene strata almost horizontally overlie Silurian strata. This shows the contact relationship between the SDL-3 and SDL-1. (B) Dipping Cretaceous strata that underwent little deformation in the central Sunan Basin. (C) Cretaceous strata in the Huangcheng Basin. From north to south, the dip angle changed from $\sim 50^{\circ}$ to $\sim 20^{\circ}$. In the central basin, Neogene strata horizontally overlie Cretaceous strata and have an unconformable contact with the pluton. (D) Pluton in the Huangcheng Basin overlain by red Neogene sandstones. The Neogene strata contact the Cretaceous strata and pluton unconformably in the eastern part of the Huangcheng Basin. K: Cretaceous strata. N: Neogene strata. r: plutons.

central basin. The Huangcheng Basin is bounded by thrust faults to the north, south, east, and northwest, unlike the Sunan Basin. The GZT is located along the northern margin of the basin, and by the branch fault of the GZT along the northwestern margin. The plutons were thrust southward toward the basin along the GZT, and Permian strata were thrust southeastward over Cretaceous strata along the CCT, forming elevated topography. On the eastern side of the basin, the Dongdahe River nearly bounds the eastern margin, while the plutons that form the elevated topography are located on the eastern side of the river. Part of the plutons remain on the western side of the river, which were covered by SDL-1 and SDL-2 (Figure 2). As in the Sunan Basin, the southern basin is bounded by the eastern segment of the NQT while the hanging wall strata are the basement strata that were thrust over the Quaternary strata. A NW-trending thrust fault cuts through the basin, which is thought to be the Huangcheng-Shuangta Fault. At the center of the basin, the basement strata have been thrust up as the hanging wall along the Huangcheng-Shuangta Fault (HSF). Moreover, the footwall has also formed a fold topping to the central basin.

In the Huangcheng Basin, the plutons are often present as the hanging wall of the faults. The elevated topography comprises the Gaizhangdaban granite plutons, which are located in the northern Huangcheng Basin. The Gaizhangdaban plutons are located $\sim 35 \mathrm{~km}$ northwest and $\sim 15 \mathrm{~km}$ northeast of the lateral ramp. The Huangcheng-Shuangta granite pluton is also located around the Huangcheng Basin, located $25 \mathrm{~km}$ to the northwest. Apatite He ages have suggested that the uplift of the HSF occurred at 12.9-14.6 Ma (Wang et al., 2020).

Similar to the YMT-S, the GZT is believed to be a fault system that thrust southward in the Huangcheng Basin during the Late Cretaceous. The GZT represents the thrust edge of the Longshou Shan thrust system.

The thrust fault system proposed in this study can be divided into two parts. Stage 1 includes motion on the YMT and the GZT, representing the older southward thrust system. Stage 2 includes motion on the NQT, which uplifted rapidly during the Cenozoic and formed elevated topography in the southern basin.

\subsection{Older Southward Vergent Thrust System}

Based on the detailed field work and mapping (Figure 4 and Figure 5), as well as the relationships between the faults and folds, we determined that the deformation styles of the Cretaceous strata and Neogene strata differ. For instance, the Neogene strata is mildly deformed, while the Cretaceous strata exhibited strong deformation near the faults plane. Hence, two separate compression events occurred in the study area, resulting in the formation of unique deformation architecture. Meanwhile, the 


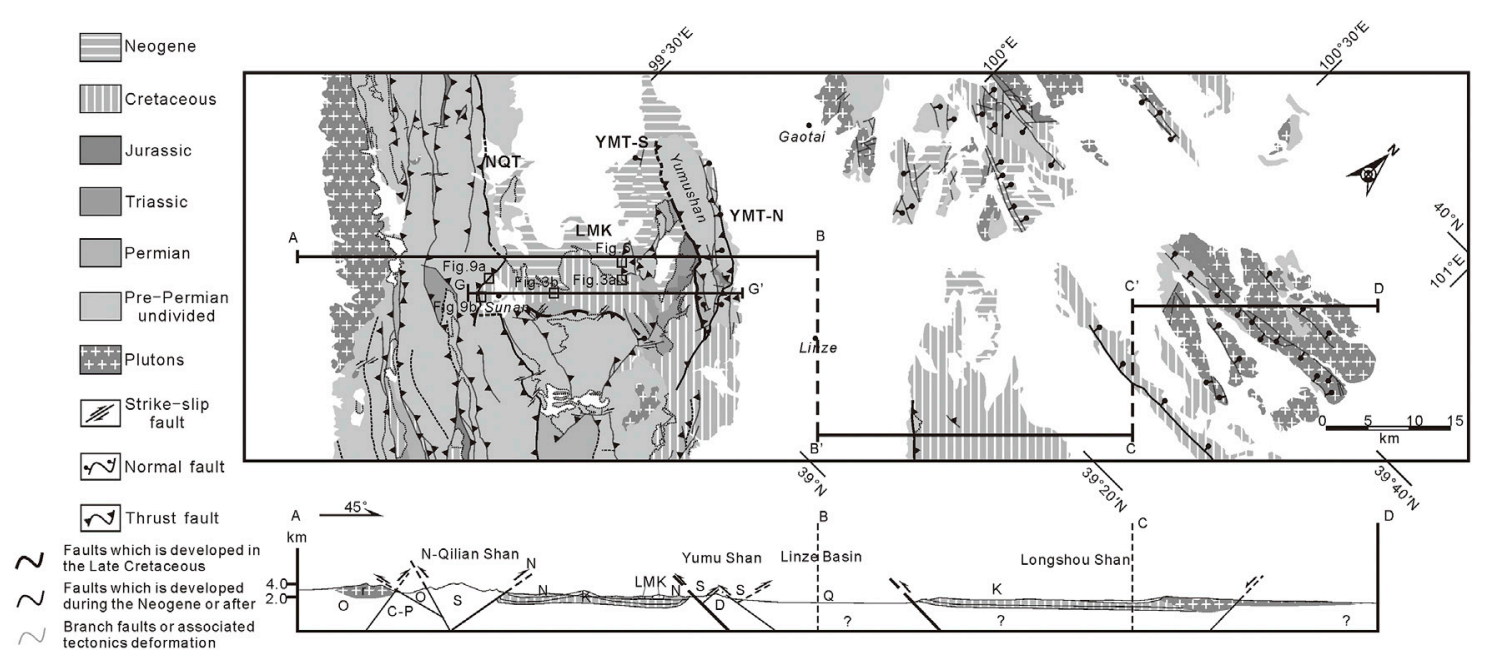

FIGURE 4 | Field map of the Sunan area. (Map based on data from the Bureau of Mineral Resources of Gansu Province (BMRGP, Regional Geological Survey) (1982), BMRIMP (1991), Bureau of Mineral Resources of Qinghai Province (BMRQP, Regional Geological Survey) (1991) and fieldwork conducted for this study).

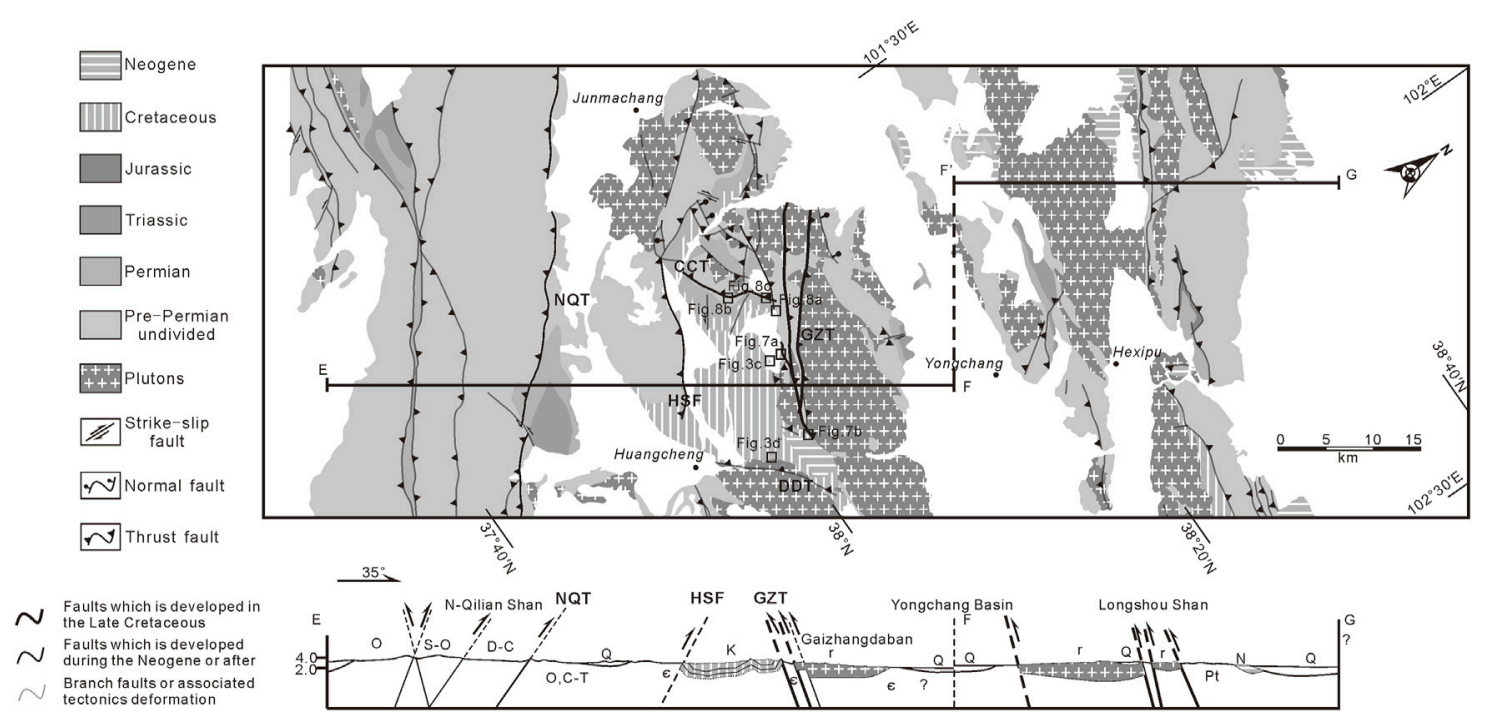

FIGURE 5 | Field map of the Huangcheng area. (Map based on data from the Bureau of Mineral Resources of Gansu Province (BMRGP, Regional Geological Survey) (1982), BMRIMP (1991), Bureau of Mineral Resources of Qinghai Province (BMRQP, Regional Geological Survey) (1991) and fieldwork conducted for this study).

southward propagation faults influence both the Cretaceous strata and Neogene strata. Additionally, the southward vergent thrust formed during the Late Cretaceous shortening event.

\subsubsection{Lamazui Klippe}

The LMK is located on the southern side of the YMT-S in the Sunan Basin (Figure 6) and extends nearly $5 \mathrm{~km}$ from east to west and $\sim 1 \mathrm{~km}$ from north to south. The strata in the klippe include Silurian lightly metamorphosed mudstones, which overlie Cretaceous sandstones. The Cretaceous strata are slightly deformed around the klippes, indicating that the footwall was not affected by the hanging wall.
The Silurian strata dip steeply around the margin and connect with the Cretaceous strata near the fracture zone. Many fault planes were observed in the fracture zone. We also observed two sets of fault planes and two sets of scratches on the planes. The scratches indicate that the thrust experienced almost NE-SW strain, which is nearly vertical to the trend along the YMT-S. In the upper wall, the klippes are covered by Neogene strata (Figure 2A), implying that the YMT-S was active between the Cretaceous and Neogene.

\subsubsection{Gaizhangdaban Thrust System}

The GZT system is located in southern Gazhangdaban, which contains the highest peak of the pluton mountains. It has a 

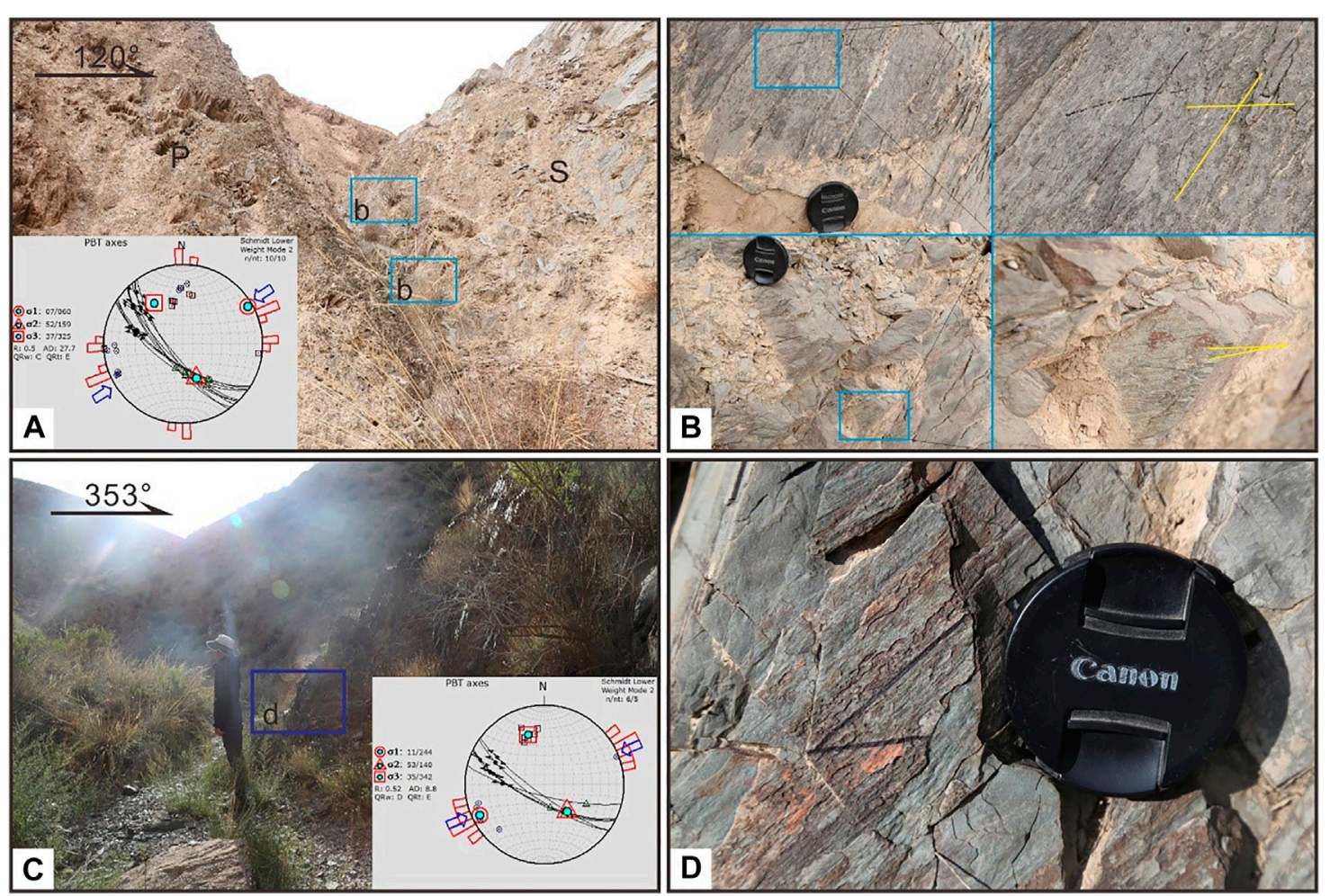

FIGURE 6 | Field photos of fault planes and scratches in the Lamazui klippe (LMK). Yellow lines mean bedding. (Figure 4 for regional location of this map). (A) Fault planes located on the southern margin of the LMK. The scratches indicate that the area underwent NE-SW compression. (B) Two sets of scratches on the fault planes. The upper scratches indicate that the tectonic activity was dominated by thrust motion, while the other set indicates that tectonic deformation was dominated by strikeslip motion. (C) Fault plane on the northern margin of the LMK. The scratches indicate that this region experienced nearly NE-SW compression. (D) Scratches on the fault plane, indicating that the fault underwent a combination of thrust and strike-slip motion. K: Cretaceous strata. N: Neogene strata.
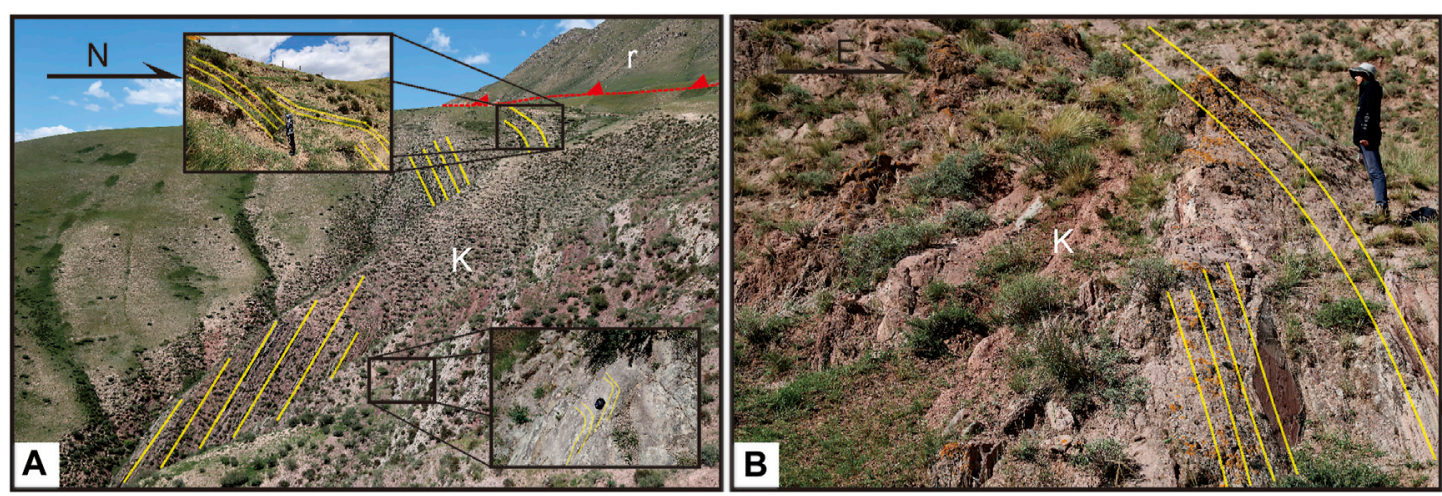

FIGURE 7 | Field photos of the GZT fault and related deformation. Yellow lines mean bedding. (Figure $\mathbf{5}$ for regional location of this map). (A) Fault plane in the southern Gaizhangdaban area, where Cretaceous strata are deformed near the fault plane. The lower strata dip $\sim 50^{\circ}$ southward, but become vertical in the middle strata. The upper strata dip northward $\sim 60^{\circ}$. The deformation exhibits a southward tectonic polarity, thereby indicating that deformation was related to southward thrust motion. (B) Folds topping to the central basin in the Shagousi area. Near the GZT, the Cretaceous strata dip vertically, while the upper strata are reversed. This fold also exhibits tectonic polarity toward the basin. K: Cretaceous strata. N: Neogene strata.

NW-SE strike and dips $\sim 70^{\circ}$ around the Gaizhangdaban area. The GZT marks the northern boundary of the Huangcheng sedimentary basin. Along this fault, the granite plutons were thrust southward over Cretaceous sandstones. This fault cuts through the plutons and overlies the Neogene strata in the southern adjacent area, indicating that the fault was not largely affected during the Neogene. 


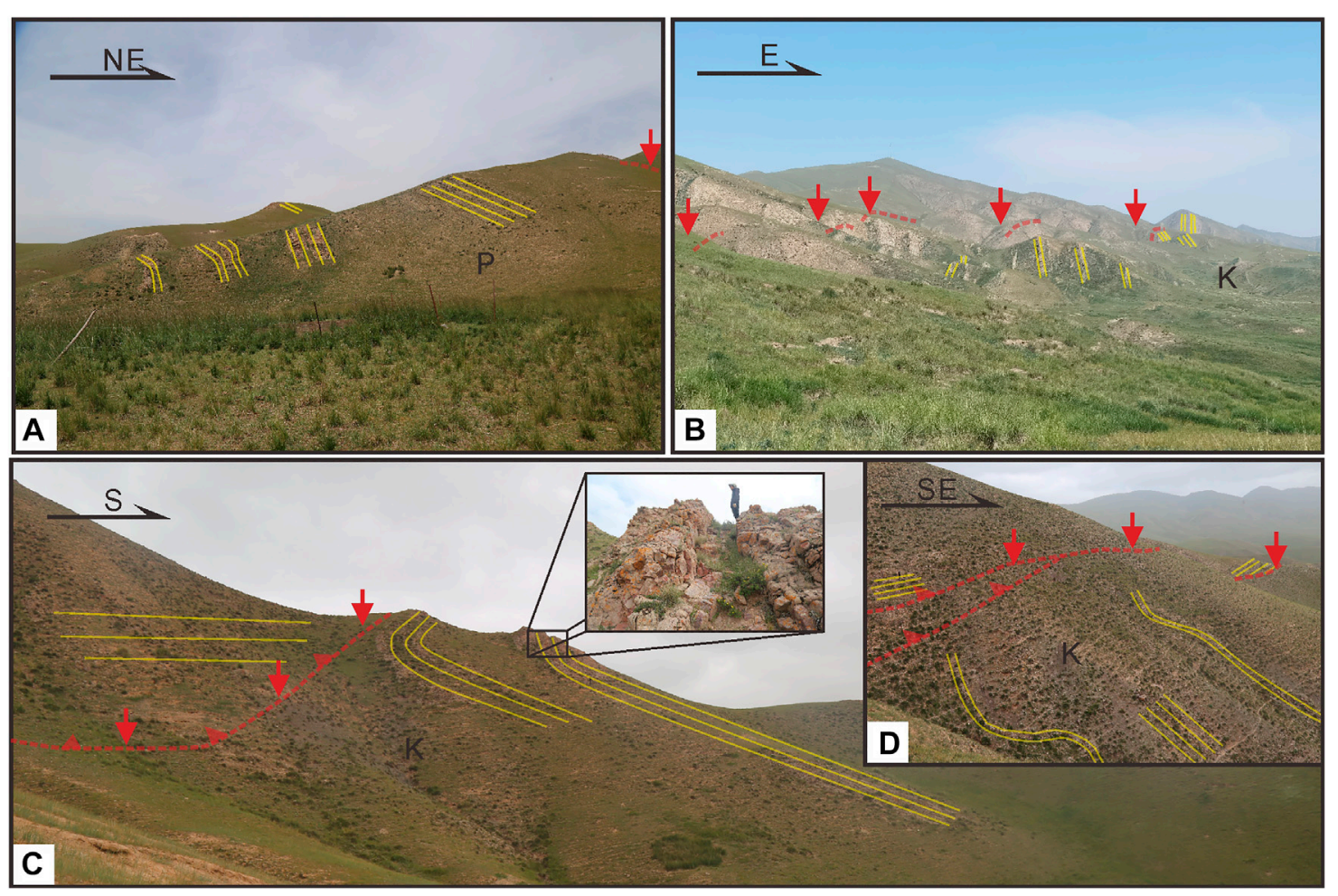

FIGURE 8 | Field photos of the CCT and related deformation. Yellow lines mean bedding. (Figure $\mathbf{5}$ for regional location of this map). (A) The CCT, located on the southern GZT, trends NE-SW. The pluton was thrust over the Permian strata and formed a fold topping to the central basin. The upper strata are reversed and become vertical in the middle part of the section. (B) The CCT, located in the western Huangcheng Basin, trends NE-SW and the fault plane is not exposed clearly. The fold topping to the central basin emerges at the eastern end of this fault, and has a SE-trending tectonic polarity that points toward the center of the basin. (C) The CCT fault, which is located in the northwestern part of the sedimentary basin in Caicaotai. The fault plane is not exposed clearly, and the footwall strata deformed as a fold topping to the central basin with a SW tectonic polarity. (D) Fault plane located at the northern end of (C). Here, the footwall deformed to produce a kink fold. the upper strata dip steeply, but become more horizontal in the middle of the section. K: Cretaceous strata. N: Neogene strata.

The footwall comprises Cretaceous thinly layered purple sandstones, which dip vertically in the middle of the section and are reversed in the upper section, forming a fold topping to the central basin at the end of the thrust fault (Figure 7). Moreover, the fold has a tectonic polarity toward the central basin. Based on these findings, we postulated that the fault was most active from the Cretaceous to the Neogene.

\subsubsection{Caicaotai Thrust System}

The CCT system is located in the southern portion of the GZT, and is thought to be a branch fault of the GZT. The fault plane is $\sim 10 \mathrm{~km}$ from the Huangcheng Basin and trends NNE-SSW. The CCT nearly bounds the Cretaceous basin in the northwest, and is cut by the HSF in the south (Figure 5).

The upper wall comprises Cambrian and Permian lightly metamorphosed sandstones, which were thrust southeastward over Cretaceous dark red sandstones. Near the fault plane, the Cretaceous strata are reversed, and some portions of the strata are vertical, indicating a southward tectonic polarity. Meanwhile, a fault broken block is present in another section of this fault, under which Cretaceous strata form a bend fold. Moreover, away from the fault plane, strata dip $\sim 20^{\circ}$ and are more stable toward the basin (Figure 8).

\subsection{Younger Northward Vergent Thrust Fault} Based on the detailed field work and mapping (Figure 4 and Figure 5), as well as the detected relationships between the faults and folds, the younger northward vergent thrust fault represented by the Qilian Shan thrust system (NQT). the Neogene strata deposit along the NQT, as well as the faults, seldom affect the Cretaceous strata. Through examination of previous study findings, it is believed that the NQT underwent intense shortening during Neogene (Zheng et al., 2010; Wang et al., 2013, 2020). We, therefore, postulate that the NQT was active later than the older south vergent thrust system.

The NQT comprises the western and eastern segments (Yang, 2007), which cover almost the entire margin of the northern Qilian Shan region. In this study, we focused on the western segment of the NQT, which is located in the southern Jiuquan Basin. The southern side of the Sunan Basin is controlled by the Fodongmiao-Hongyazi thrust segment of the NQT (Yang, 2007), which trends NW. The fault plane dips at $60^{\circ}-75^{\circ}$ (BMRGP, 1982). The NQT thrust belt formed imbricate fans and thrust northward over Cretaceous strata.

The western segment of the NQT, located in southern Sunan Province, is the leading edge of the Qilian Shan thrust system. In 

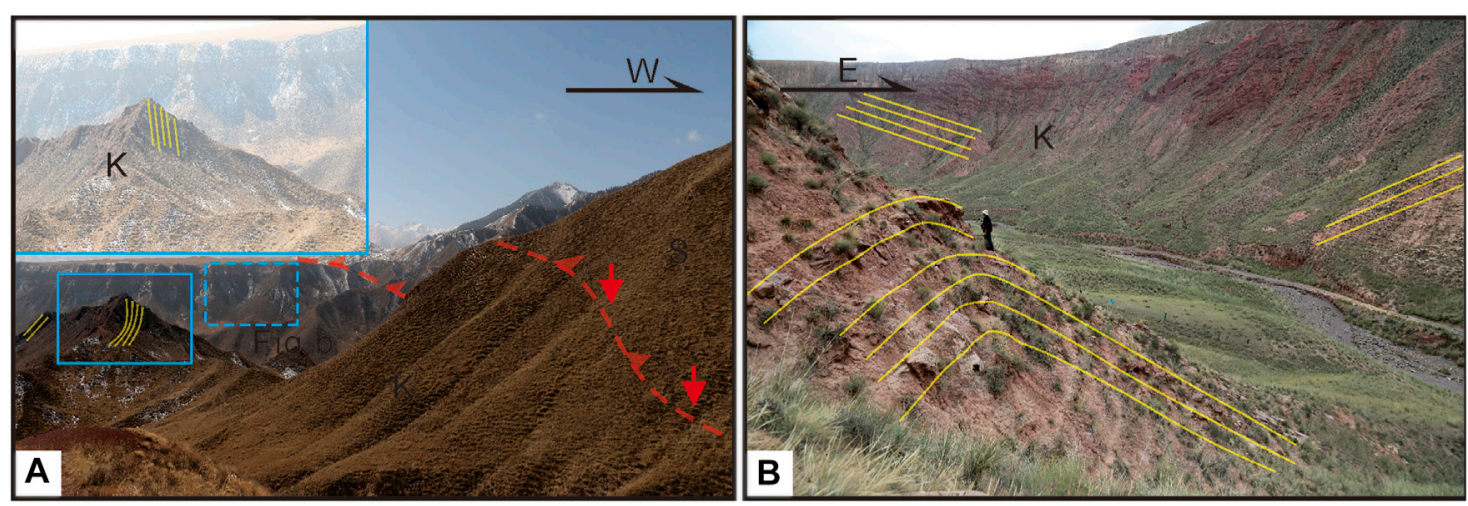

FIGURE 9| Field photos of the NQT and its folds in the footwall strata. Yellow lines mean bedding. (Figure 4 for regional location of this map). (A) Field photos of the NQT and Cretaceous strata in the footwall of the fault. The upper section's Cretaceous strata deformed and are steeply dipping. (B) Field photos of Cretaceous strata near the NQT fault plane. K: Cretaceous strata. N: Neogene strata.

the western area around Sunan Province, the NQT is thrust over Neogene strata and dips NE at $\sim 60^{\circ}$. In the middle section of the NQT, Triassic strata are present and believed to be tectonic windows. The structural style of the NQT is an imbricate fan along the northeastern Qilian Shan region (Figure 1). The hanging wall comprises lightly metamorphosed Silurian mudstones that overlie Cretaceous sandstones and are covered by Neogene strata, in which the strata reverse and form a NEtrending tectonic polarity. The upper strata of the Cretaceous footwall were affected by the NQT and became reversed, then became steeper in the middle section, and finally became vertical (Figure 9).

\section{POLYCYCLIC MODEL AND THRUST MECHANISM}

In the study area, we observed two sets of fold and thrust fault systems. One set of faults is believed to be an older regional thrust system that was active after the Cretaceous and before the Neogene. The other set of thrust systems (comprising the YMT-N, NQT, and HSF) is believed to result from the northeastward propagation of the Tibetan Plateau, which has been active since the Neogene. In addition to the thrust systems, the older thrusts formed the LMK, while the Yumu Shan and Gaizhangdaban serve as the upper walls of the southward thrust edge. The younger thrust system propagated northward and is expected to cut through, or reactivate, the older thrust system, forming multiple tectonism episodes. The most typical deformation style in this orogenic belt is northward thrust, which includes the NQT and the HSF.

The sedimentary basins are dustpan shaped and filled with Cretaceous and Neogene strata. Based on the field mapping, the strata of the Cretaceous strata revealed that the fold hinge is NW-trending, indicating that the field strain is NE-trending. With the appearance of the extrusion events, the fold hinge rotated.

\subsection{Polycyclic Model for the Basin}

The shortening rate of the Neogene Qilian Shan strata during the Cenozoic can be used to answer questions regarding the Qilian Shan uplift (Zhang et al., 2004). We observed two sets of fold and thrust pairs in the Sunan and Huangcheng basins. If the tectonic style of each tectonic activity can be identified, the tectonic deformation in the study area can be used to characterize the older tectonic mechanisms and forecast future tectonic evolution. Three main features are common to recognizing out of sequence thrust faults: basic ramp-flat geometry, fault-related folds, and detachments between the basement and upper covering strata ( $\mathrm{Li}$ et al., 2016).

Based on these features, the YMT and LMK belong to the regional thrust system in the Sunan Basin, whereas the GZT and CCT belong to the regional thrust system in the Huangcheng Basin, which is the fold and thrust system that was present prior to the Cenozoic thrust system (NQT). The regional system comprised a set of low-angle thrust faults and produced regional shortening of the Cretaceous strata, which are deformed more strongly near the thrust faults, however, are more stable in the interior aspect of the basin. All of the regional thrust systems dip steeply northward and were present along the northern margin of the basin. We, therefore, propose that these regional thrust systems experienced the northward propagation of Cenozoic thrust tectonism that formed southward-dipping thrust systems (YMT-N and HSF). These systems are still developing, being reactivated, and becoming more steeply dipping.

We observed a fold topping to the central basin in the southern GZT, indicating that the YMT-S and GZT controlled the northern basin during the Late Cretaceous and formed elevated topography. By analyzing the relationships between the unconformities and the fold and thrust system, we established a fault evolution model for the Sunan Basin and compared the deformation style with those of regional thrusting and the NQT.

When the model was initiated, hinterland rifted systems were present (Yang, 2007), wherein the Cretaceous strata trended W-E 


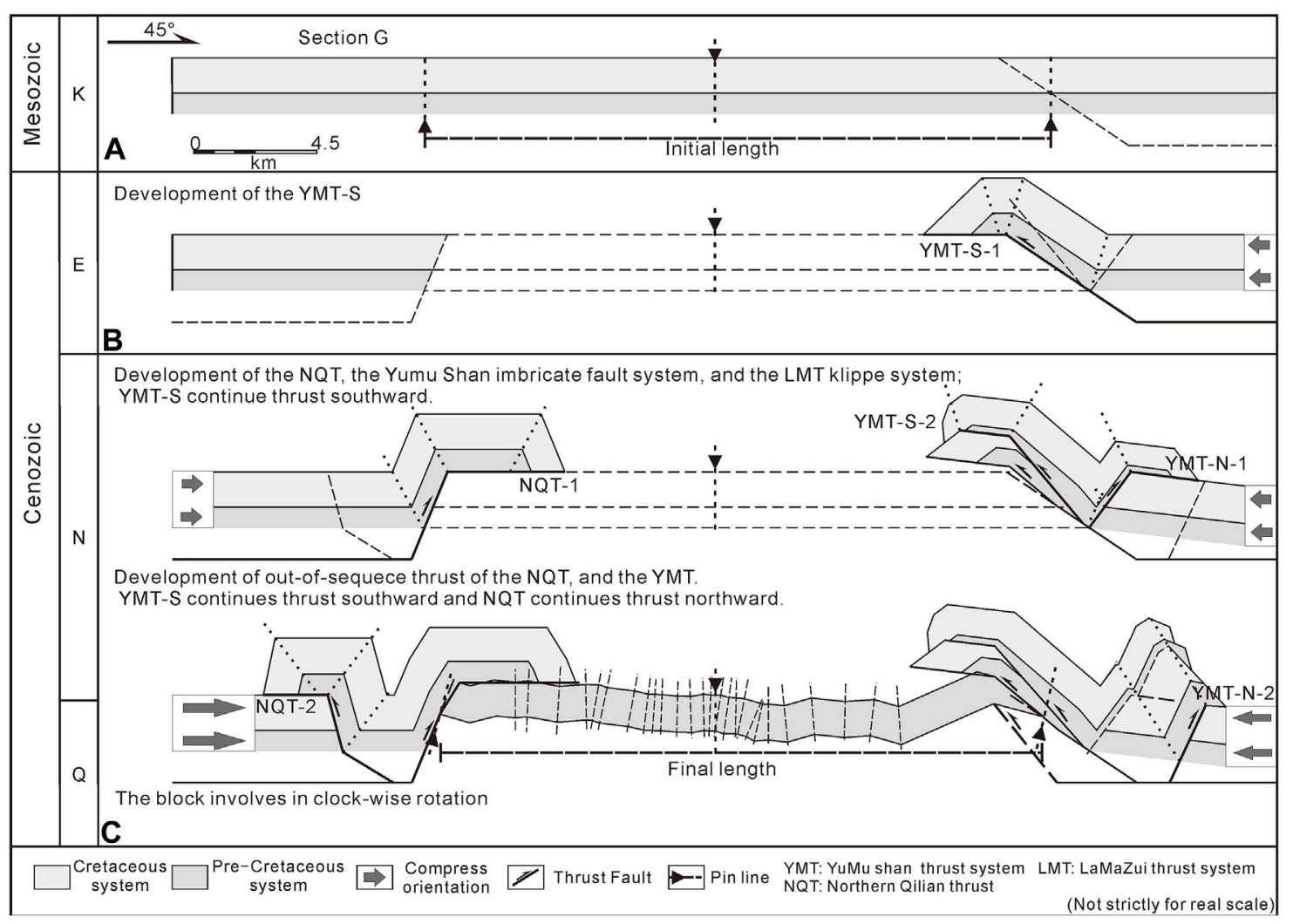

FIGURE 10 | Model of the fault system development in the study area. (A-C) Fault propagation and strata deformation process. (A) The restored initial length of the Cretaceous strata is shown (based on the strata data of this study); (C) The final length of the Cretaceous strata of this section. Each of the dotted lines represent the fold hinge, based on the field work of this study and the thickness of the strata is based on the Bureau of Mineral Resources of Gansu Province (BMRGP, Regional Geological Survey) (1982).

(Figure 10A). Owing to the collision between the Alashan and Qiangtang blocks, southward propagation of the thrusting began, forming a regional thrust system (YMT-S and GZT) (Figure 10B). At this stage, slight differences can be observed between the Sunan and Huangcheng basins. The YMT-S developed during the Late Triassic $(\sim 100 \mathrm{Ma})$ to the early Neogene (Figure 2); however, the GZT in the Huangcheng Basin developed later, possibly since $80 \mathrm{Ma}$. Both thrust faults are not currently well-exposed, owing to the burial of the Neogene strata, and the fault surface is not well preserved. However, their deformation styles can be defined by the fault-related folds described above, which indicate that these faults are at their farthest extents during this time. During this process, the Yumu Shan and Gaizhangdaban areas began uplifting forming elevated topography.

As the collision between the two blocks continued, the YMT developed more branch faults, forming an imbricate fan in the Yumu Shan region (Figure 10C). In the Huangcheng Basin, along the propagation of the GZT, volcanism formed plutons. This phase of shortening stopped after $\sim 65.5 \mathrm{Ma}$ when an unconformity formed between the Cretaceous and Neogene strata (Figure 1). The Cenozoic thrust system may have developed after the deposition of the Eogene conglomerates, which were uplifted rapidly at $\sim 10 \mathrm{Ma}$ in the western Sunan
Basin (Zheng et al., 2010), at $\sim 15 \mathrm{Ma}$ in the Huangcheng Basin along the HSF (Wang et al., 2020), and at 17-15 Ma along the Tuolai Shan in the central Qilian Shan region (Yu et al., 2019).

With the northward propagation of the NQT, the YMT may have formed the YMT-N, after which the YMT-S, GZT, and CCT began to tilt, reactivate, and steepen (Figure 10). Moreover, the development of the back-thrust fault in the NQT and the uplift of the YMT and GZT caused the Cretaceous strata in the basin to undergo folding.

Several cross sections have been restored using seismic reflection data, indicating that the northern margin of the Tibetan Plateau accumulated the majority of its compressive strain from the Jurassic to the Cretaceous (Zuza et al., 2016). From the Cretaceous to the present, the northeastern Tibetan Plateau has shortened by approximately 50\% (Yang, 2007; Zuza et al., 2016), 43-49\% shortening in the Altyn Tagh-Qilian Shan (Cheng et al., 2015) and $48 \%$ in the west Qaidam Basin (Yin et al., 2008b). The restored cross sections also indicate that the middle and upper crust exhibit strike-slip deformation and tectonic extrusion (Guo et al., 2016). However, the shortening rate of the Cenozoic strata in the Sunan Basin remains controversial. 
Through our detailed field mapping and data from geologic maps (BMRGP, 1982), in the last tectonic evolutionary stage, we restored Section G (extending across the Sunan Basin) with the Cretaceous strata in the initial length (Figure 10A), and compared it with the final length of the cross-section map (Figure 10C). Our results revealed that the Cretaceous folding system accumulated $\sim 3.56 \%$ of the regional shortening in the Sunan Basin from northeast to southwest, which was significantly less than the $\sim 50 \%$ crustal shortening accumulated through thrust propagation (Zuza et al., 2020). Taken together, these findings suggest that the block in the Qilian Shan did not only absorb the shortening through the north and south vergent thrust-fold system, but also through extrusion, strike-slip, and block rotation tectonic activities. However, the NQT propagation is ongoing and may reactivate older thrust faults with the potential to cause the formation of active faults along the northern margin of the Yumu Shan and Gaizhangdaban areas.

\subsection{Deformation Response of the Simulated Fold Hinge}

For the regional thrust system, the deformation style is believed to be that of a traditional thrust system, which forms in the hinterland (Davis et al., 1998). However, both basins exhibited different deformation styles in the foreland fold and thrust belts. The sedimentary basins are dustpan shaped and filled with Cretaceous and Neogene strata. However, it is unknown whether this topography formed before the Cretaceous or in the Cenozoic because of the India-Eurasian plate collision. In addition to the sedimentary basins, the hanging walls of the regional thrusts were exposed differently. The hanging walls mark the area adjacent to the basin on the northern, eastern, and southern sides, and on the northern and eastern sides of the hanging walls. The strata appear to have experienced clockwise rotation, as well as thrust motion.

To address these issues, we generated sets of stereographic projections, which suggest that the strike trends and the fold hinge are located in different parts of the Cretaceous strata (Figure 11). In the Sunan Basin, the thrust fault system trends almost NW-SE as the fold hinges. In the eastern portion of the Yumu Shan (S-4 and S-5) near the Liyuanpu Fault (LYF) (Wang et al., 2021), the fold hinge has a $\sim 133^{\circ}$ trend and a $\sim 23^{\circ}$ plunge that is right-laterally rotated by $\sim 13^{\circ}$. In the northern aspect of the Sunan Basin (S-1), the fold hinge trends almost $\mathrm{W}$ and has a $15^{\circ}$ plunge that has been left-laterally rotated $\sim 25^{\circ}$ from the NW. In the central portion of the basin (S-2), the fold hinge is almost undefinable and the strata are nearly parallel, at $\sim 12^{\circ}$ toward the north. Hence, we suggest that the strata in Sunan area are the southern limb of the syncline fold (S-1). In the southern part of the Sunan Basin, where folding primarily occurred as folds topping to the central basin, the fold hinges trend $\sim 327^{\circ}$ and have a $6^{\circ}$ plunge that was right-laterally rotated by $\sim 24^{\circ}$. Based on these data, we suggest that the Sunan Basin was dominated by NE-SW compression from the Late Cretaceous to the Neogene. The fold hinge trend is the opposite in the Sunan Basin and around the LYF; thus, fold deformation was altered by the NW-SE compressive strain. During the most recent tectonic stage, the fold deformation evolved as the block gently rotated. Meanwhile, some researchers have postulated that the Qilian Shan is not involved in block rotation (Wang et al., 2002).

In the Huangcheng Basin, fold deformation throughout the area differs from that in the Sunan Basin. We believe that both study areas are dominated by the NE-SW trending compression. In the Huangcheng Basin, this formed the GZT and HSF. The fold hinges in the basin ( $\mathrm{H}-2, \mathrm{H}-3$, and $\mathrm{H}-4)$ trend $\sim 130^{\circ}$ and plunge $\sim 20^{\circ}$, all of which are seldomly rotated. Based on the plunge, the thrust of the CCT influenced the entire area and formed elevated topography in the northwestern portion of the basin. In addition to the southeastward trending folds in the southern aspect of the basin (H-1), the Cretaceous strata trend $39^{\circ}$ northeastward and plunge $\sim 4^{\circ}$. Thus, the fold deformation in this area remains unclear.

\subsection{Thrust System Mechanism}

We established a model to explain the topography observed in the study area (Figure 12). Prior to the Cretaceous, crustal shortening of the craton in the Alashan Block thrust downward into the northern Qilian Shan (Yin and Harrison, 2000; Zuza et al., 2016). Two phases of N-S tectonic extension (Chen et al., 2003) formed rifted basins or topographic depressions (Wang et al., 2021) in the Sunan and Huangcheng basins, which resulted from the evolution of the suture belt. The rifted basins were then filled with Cretaceous and Neogene strata. During compression, due to the Songpan-Ganzi and Alashan blocks, the regional thrust faults began to thrust southward and vertically to the eastern margin of the rifted basin, thereby causing the basin margin to become a lateral ramp and forming a tear fault. The Cenozoic strata in the northern Qaidam basin may source from Qilian Shan and the southern Qaidam Basin (Lu et al., 2018), and it indicates that the strata materials in the Qaidam Basin are severed by the northern Qaidam thrust belt (Cheng et al., 2021). According to the source trace of the Lower Cretaceous strata, the ages of the Cretaceous strata are consistent with those of the basement rocks in the Alashan area and in the North China Block (Wang et al., 2021) and most of the materials in the northern Sunan Basin originate from the Bei Shan (Cheng et al., 2019a), indicating that the Alashan Block had a higher topography during the Mesozoic than the current location of the Qilian Shan.

The thrust faults continued to thrust southward and form elevated topography along the northern margin of the sedimentary basin. As for the lateral ramp, the thrust fault plane was rotated and torn apart, forming a tear fault to accommodate the shortening, which then created elevated topography on the eastern side of the basin and lower topography toward the center of the sedimentary basin. Based on the source trace of the strata in the basin, this belt may have developed higher topography than that of the northern Qilian Shan prior to the Cretaceous (Wang et al., 2021).

During the Early Cenozoic, regional southward thrusting seldom propagated, and Neogene strata were deposited on top of the YMT and GZT. The source trace of the Miocene strata indicates that the sediment source was the plutons in the Alashan 


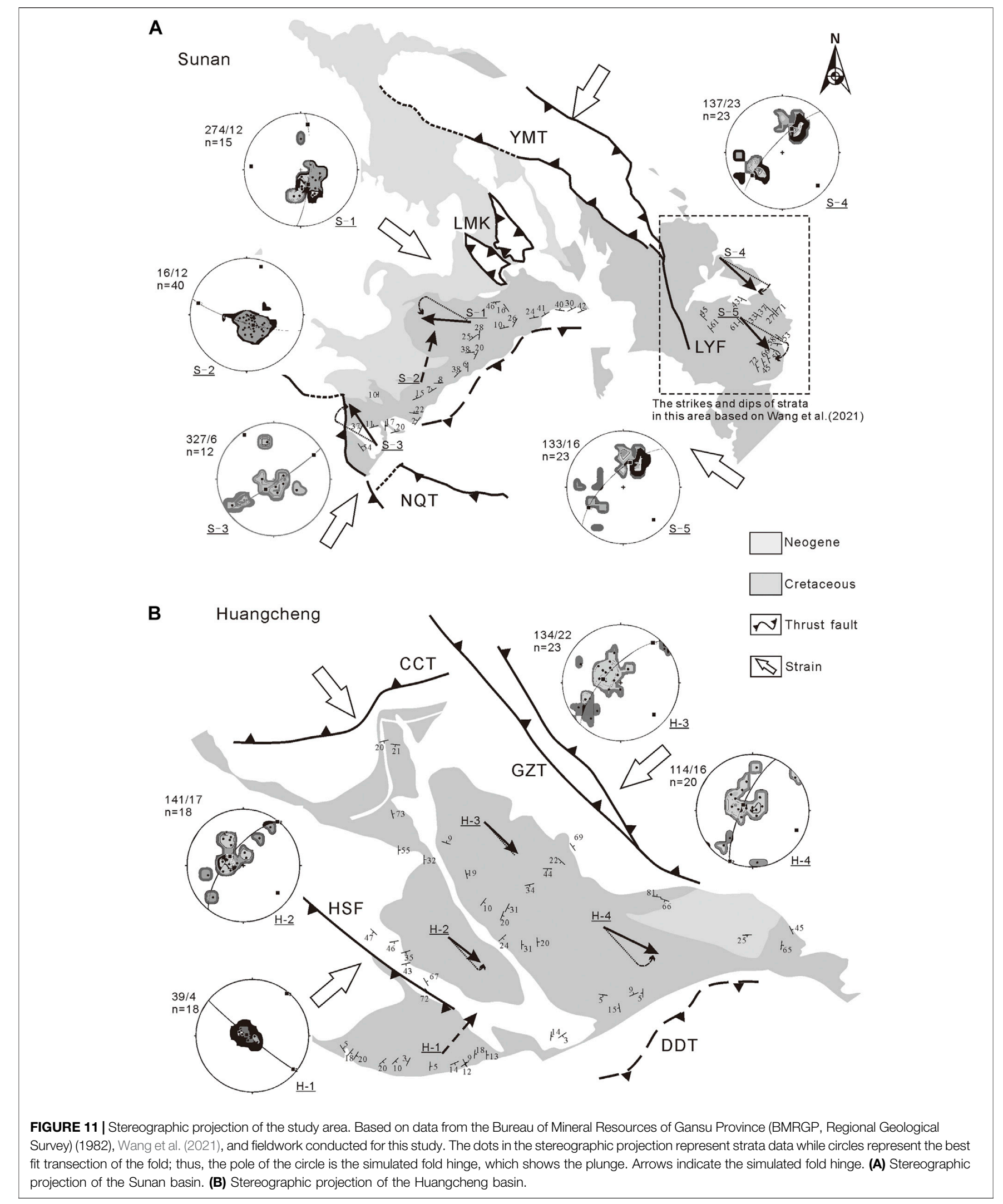




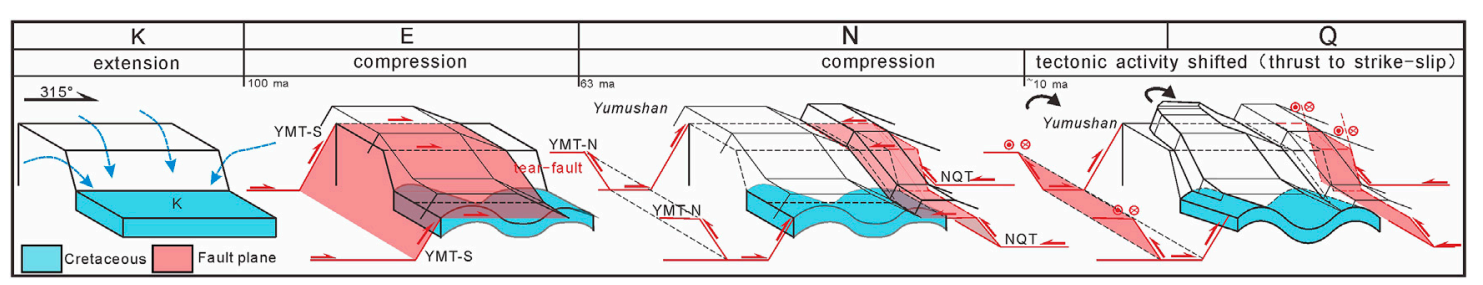

FIGURE 12 | Model of the tectonic evolution of the Sunan area (not strictly to scale). Cretaceous strata deformation history of Sunan Basin, fault plane propagation history, and kinematic characteristics of the strata block through time and tectonic activities, are shown.

area (Wang et al., 2021), which indicates that the strata were uplifted and volcanism, controlled by the YMT and GZT, occurred before the uplift of the Qilian Shan. The hanging walls in the basin are also eroded more than those on the eastern side of the basin, owing to water erosion. Thus, a portion of the hanging wall strata remains on the eastern side of the adjacent rifted basin and forms rivers in the adjacent area, including the Dongdahe River, located along the lateral ramp (Figure 12).

The convergence of the Indian and Eurasian plates began at $\sim 50 \mathrm{Ma}$ (Yin, 2000), and produced volcanism along with thrust. The Qilian Shan experienced a NE-SW trending compression strain in the Early Cenozoic (Cheng et al., 2019a). Apatite He ages of the plutons around the western segment of the NQT indicate that the NQT in the Sunan area initially created steep topography at $\sim 10 \mathrm{Ma}$ (Zheng et al., 2010). The intense exhumation events occurred at the beginning of the Mesozoic (Lin et al., 2021). Meanwhile, the sedimentary history of basin has indicated that shortening began at $\sim 10 \mathrm{Ma}$ (Wang et al., 2013; Wang et al., 2017). The Qilian Shan may have been uplifted during the Late Miocene, based on the rapid accumulation in the Sikouzi Basin at $\sim 10.5 \mathrm{Ma}$ (Wang et al., 2011) and rapid exhumation of faults in the northeastern Qilian Shan at $\sim 15 \mathrm{Ma}$ (Zheng et al., 2010; Wang et al., 2020), forming high topography. The deformation propagation continues toward the Longshou Shan and Heli Shan regions (Zheng et al., 2013).

On the eastern segment of the NQT in the southern Huangcheng Basin, the HSF is thought to be a branch fault of the NQT, which remains active today. Moreover, the Apatite $\mathrm{He}$ ages indicate that the HSF was rapidly exhumed at $\sim 15 \mathrm{Ma}$ (Wang et al., 2020). Moreover, the thrust system on the northeastern margin of the Tibetan Plateau maintained thrust and strike-slip motions (Zheng et al., 2010; Wang et al., 2020). This resulted in strata rotation and left-lateral thrust faults, thereby causing the folding and rotation of the Cretaceous strata in the Sunan and Huangcheng basins. The most likely mechanism for the propagation of the plateau is far-field stress related to the tectonic plate collision. As a result of the propagation of the NQT, the northern regional thrust planes (YMT-S and GZT) dipped more steeply and developed backthrust faults (YMT-N), enabling the potential reactivation of older thrust faults and topographic uplifts throughout the area.

Based on thermochronological results, the Haiyuan Fault, which is located in the eastern Qilian Shan, shifted from thrust to left-lateral strike-slip motion (Wang et al., 2020). This kind of tectonic shift might have affected the western and central portions of the Qilian Shan-Hexi corridor, which accumulates crustal shortening by eastward block extrusion and rotation in the upper crust. Based on the evidence obtained herein, we postulate that the older Tibetan Plateau growth boundary terminates at the northern margins of the Yumu Shan and Gaizhangdaban by forming an active fault and reproducing the older regional fault. The outgrowth of the Tibetan Plateau may still propagate northeastward, combined with block extrusion toward the east. We also suggest that the subduction of the Alashan Block is ongoing.

\section{CONCLUSION}

The Qilian Shan orogenic belt is a typical continental collision area characterized by vergent fold and thrust deformation. Older southward vergent thrusts were reactivated by a younger northward thrust system and covered by Neogene strata. The first shortening event was characterized by southward regional thrust systems that developed from the Late Cretaceous to the Neogene, which were constrained by the thrust fault planes covered by Neogene strata. The older regional thrusts are the YMT and GZT, which are characterized by steep fault planes and folds topping to the central basin. The second shortening event began in the Neogene, in which the Qilian Shan propagated northeastward toward the Hexi corridor and rapidly uplifted the NQT, which was produced by the Indian-Eurasian tectonic collision. After two phases of convergence, deformation of the Cretaceous sedimentary basin occurred, and the basin developed fault-related folds that accommodated $\sim 3.56 \%$ of the NE-SW shortening in this area.

To investigate the basin shape, we established a deformation model of the study area. Initially, the development of a rifted basin established a depositional setting; thus, the northern Qilian Shan region has lower topography. Subsequently, southward thrust motion and the development of a tear fault formed the contours of the basin and produced elevated topography in the northern and eastern aspects of the basin. When tectonic strain shifted in the Miocene, the deformation (including folds and thrusts) was reactivated by the strike-slip activity and block rotation.

The Qilian Shan-Hexi corridor exhibits typical continental orogenic deformational characteristics. These opposing vergent thrust faults and fault-related folds accommodated the shortening of the propagating Tibetan Plateau, and can be used to define the tectonic evolution of the northeastern Tibetan Plateau. 


\section{DATA AVAILABILITY STATEMENT}

The raw data supporting the conclusion of this article will be made available by the authors, without undue reservation.

\section{AUTHOR CONTRIBUTIONS}

JJ did the field work, field mapping, and wrote the manuscript. $\mathrm{WZ}$ contributed to the conception and provided funding for the study. SL, QT, SW, CF, and YZ did the field work. SL, QT, and SW and reviewed and edited the manuscript. All authors contributed to manuscript revision and discussion and approved the submitted version.

\section{REFERENCES}

Bureau of Mineral Resources of Gansu Province (1982). BMRGP, Regional Geological Survey. Beijing, China: Ministry of Geology of China.

Bureau of Mineral Resources of Inner Mongolia Province (1991). BMRIMP, Regional Geological Survey. Beijing, China: Ministry of Geology of China.

Bureau of Mineral Resources of Qinghai Province (1991). BMRQP, Regional Geological Survey. Beijing, China: Ministry of Geology of China.

Chen, X., Yin, A., Gehrels, G. E., Cowgill, E. S., Grove, M., and Harrison, T. M. (2003). Two Phases of Mesozoic north-south Extension in the Eastern Altyn Tagh Range, Northern Tibetan Plateau. Tectonics 22. doi:10.1029/ 2001 TC001336

Cheng, F., Garzione, C., Jolivet, M., Wang, W., Dong, J., Richter, F., et al. (2019a). Provenance Analysis of the Yumen Basin and Northern Qilian Shan: Implications for the Pre-collisional Paleogeography in the NE Tibetan Plateau and Eastern Termination of Altyn Tagh Fault. Gondwana Res. 65, 156-171. doi:10.1016/j.gr.2018.08.009

Cheng, F., Jolivet, M., Dupont-Nivet, G., Wang, L., Yu, X., and Guo, Z. (2015). Lateral Extrusion along the Altyn Tagh Fault, Qilian Shan (NE Tibet): Insight from a 3D Crustal Budget. Terra Nova 27, 416-425. doi:10.1111/ter. 12173

Cheng, F., Jolivet, M., Guo, Z., Lu, H., Zhang, B., Li, X., et al. (2019b). Jurassic-Early Cenozoic Tectonic Inversion in the Qilian Shan and Qaidam basin, North Tibet: New Insight from Seismic Reflection, Isopach Mapping, and Drill Core Data. J. Geophys. Res. Solid Earth. 124, 12077-12098. doi:10.1029/2019jb018086

Cheng, F., Jolivet, M., Guo, Z., Wang, L., Zhang, C., and Li, X. (2021). Cenozoic Evolution of the Qaidam basin and Implications for the Growth of the Northern Tibetan Plateau: A Review. Earth Sci. Rev. 220. doi:10.1016/j.earscirev.2021. 103730

Clark, M. K., Farley, K. A., Zheng, D., Wang, Z., and Duvall, A. R. (2010). Early Cenozoic Faulting of the Northern Tibetan Plateau Margin from Apatite (U-Th)/He Ages. Earth Planet. Sci. Lett. 296, 78-88. doi:10.1016/j.epsl.2010. 04.051

Dai, S., Fang, X., Dupont-Nivet, G., Song, C., Gao, J., Krijgsman, W., et al. (2006). Magnetostratigraphy of Cenozoic Sediments from the Xining basin: Tectonic Implications for the Northeastern Tibetan Plateau. JGR Solid Earth 111, B11102. doi:10.1029/2005jb004187

Davis, G. A., Wang, C., Zheng, Y., Zhang, J., Zhang, C., and Gehrels, G. E. (1998). The Enigmatic Yinshan Fold-And-Thrust belt of Northern China: New Views on its Intraplate Contractional Styles. Geology 26. doi:10.1130/0091-7613(1998) 026<0043:teyfat $>2.3 . c 0 ; 2$

Dayem, K. E., Molnar, P., Clark, M. K., and Houseman, G. A. (2009). Far-field Lithospheric Deformation in Tibet during continental Collision. Tectonics 28, TC6005. doi:10.1029/2008tc002344

Elliott, D. (1983). The Construction of Balanced Cross-Sections. J. Struct. Geol. 5, 101. doi:10.1016/0191-8141(83)90035-4

\section{FUNDING}

This work is supported by the Second Tibetan Plateau Scientific Expedition and Research Program (STEP) (2019QZKK0901), National Natural Science Foundation of China (Grant Nos 42030301, 41872204, 41590861), and Guangdong Province Introduced Innovative R\&D Team of Geological Processes and Natural Disasters around the South China Sea (2016ZT06N331).

\section{ACKNOWLEDGMENTS}

We are grateful to Yigen Qin and Gan Chen for their guidance during the manuscript writing process.

Guo, X., Gao, R., Li, S., Xu, X., Huang, X., Wang, H., et al. (2016). Lithospheric Architecture and Deformation of NE Tibet: New Insights on the Interplay of Regional Tectonic Processes. Earth Planet. Sci. Lett. 449, 89-95. doi:10.1016/j. epsl.2016.05.045

He, P., Song, C., Wang, Y., Wang, D., Chen, L., Meng, Q., et al. (2021). Early Cenozoic Activated Deformation in the Qilian Shan, Northeastern Tibetan Plateau: Insights from Detrital Apatite Fission-track Analysis. Basin Res. 33, 1731-1748. doi:10.1111/bre.12533

Hu, X., Garzanti, E., Moore, T., and Raffi, I. (2015). Direct Stratigraphic Dating of India-Asia Collision Onset at the Selandian (Middle Paleocene, $59 \pm 1 \mathrm{Ma}$ ). Geology 43, 859-862. doi:10.1130/g36872.1

Jin, Z., Cunningham, D., and Hongyi, C. (2010). Sedimentary Characteristics of Cenozoic Strata in central-southern Ningxia, NW China: Implications for the Evolution of the NE Qinghai-Tibetan Plateau. J. Asian Earth Sci. 39, 740-759. doi:10.1016/j.jseaes.2010.05.008

Jolivet, M., Brunel, M., Seward, D., Xu, Z., Yang, J., Roger, F., et al. (2001). Mesozoic and Cenozoic Tectonics of the Northern Edge of the Tibetan Plateau: FissionTrack Constraints. Tectonophysics 343, 111-134. doi:10.1016/s0040-1951(01) 00196-2

Li, C., Zhang, C., Cope, T. D., and Lin, Y. (2016). Out-of-sequence Thrusting in Polycyclic Thrust Belts: An Example from the Mesozoic Yanshan belt, North China Craton. Tectonics 35, 2082-2116. doi:10.1002/2016tc004187

Lin, X., Jolivet, M., Liu-Zeng, J., Cheng, F., Tian, Y., and Li, C. a. (2021). Mesozoic-Cenozoic Cooling History of the Eastern Qinghai Nan Shan (NW China): Apatite Low-Temperature Thermochronology Constraints. Palaeogeogr. Palaeoclimatol. Palaeoecol. 572. doi:10.1016/j.palaeo.2021.110416

Lu, H., Ye, J., Guo, L., Pan, J., Xiong, S., and Li, H. (2018). Towards a Clarification of the Provenance of Cenozoic Sediments in the Northern Qaidam basin. Lithosphere 11, 252-272. doi:10.1130/11037.1

Pan, B., Li, Q., Hu, X., Geng, H., Liu, Z., Jiang, S., et al. (2013). Cretaceous and Cenozoic Cooling History of the Eastern Qilian Shan, north-eastern Margin of the Tibetan Plateau: Evidence from Apatite Fission-Track Analysis. Terra Nova 25, 431-438. doi:10.1111/ter.12052

Wang, E., Meng, K., Su, Z., Meng, Q., Chu, J. J., Chen, Z., et al. (2014). Block Rotation: Tectonic Response of the Sichuan basin to the Southeastward Growth of the Tibetan Plateau along the Xianshuihe-Xiaojiang Fault. Tectonics 33, 686-718. doi:10.1002/2013tc003337

Wang, Q., Wang, W., Cui, D., Zhu, G., and Liang, W. (2002). Present-day Crustal Movement of Northeastern Margin of Qinghai-Tibet Block. J. Geod. Geodynamic. 22.

Wang, W., Kirby, E., Zhang, P., Zheng, D., Zhang, G., Zhang, H., et al. (2013). Tertiary basin Evolution along the Northeastern Margin of the Tibetan Plateau: Evidence for basin Formation during Oligocene Transtension. Geol. Soc. Am. Bull. 125, 377-400. doi:10.1130/b30611.1

Wang, W., Zhang, P., Kirby, E., Wang, L., Zhang, G., Zheng, D., et al. (2011). A Revised Chronology for Tertiary Sedimentation in the Sikouzi basin: Implications for the Tectonic Evolution of the Northeastern Corner of the Tibetan Plateau. Tectonophysics 505, 100-114. doi:10.1016/j.tecto.2011.04.006 
Wang, W., Zheng, D., Li, C., Wang, Y., Zhang, Z., Pang, J., et al. (2020). Cenozoic Exhumation of the Qilian Shan in the Northeastern Tibetan Plateau: Evidence from Low-Temperature Thermochronology. Tectonics 39. doi:10.1029/ 2019 tc005705

Wang, W., Zheng, W., Zhang, P., Li, Q., Kirby, E., Yuan, D., et al. (2017). Expansion of the Tibetan Plateau during the Neogene. Nat. Commun. 8, 15887. doi:10. 1038/ncomms 15887

Wang, X., Deng, L., Zattin, M., Ji, M., and Li, J. (2017). Palaeogene Growth of the Northeastern Tibetan Plateau: Detrital Fission Track and Sedimentary Analysis of the Lanzhou basin, NW China. J. Asian Earth Sci. 147, 322-331. doi:10.1016/ j.jseaes.2017.07.020

Wang, Y., Chen, X., Zhang, Y., Yin, Z., Zuza, A. V., Yin, A., et al. (2021). Superposition of Cretaceous and Cenozoic Deformation in Northern Tibet: A Far-Field Response to the Tectonic Evolution of the Tethyan Orogenic System. GSA Bull. 134, 501-525. doi:10.1130/b35944.1

Xiao, W., Windley, B. F., Yong, Y., Yan, Z., Yuan, C., Liu, C., et al. (2009). Early Paleozoic to Devonian Multiple-Accretionary Model for the Qilian Shan, NW China. J. Asian Earth Sci. 35, 323-333. doi:10.1016/j.jseaes.2008.10.001

Yang, S. (2007). Structural Features and Petroleum Prospects of Thrust belt in the Northern Margin of Qilian Mountains. Beijing: Science Press. (in Chinese).

Yin, A. (2006). Cenozoic Tectonic Evolution of the Himalayan Orogen as Constrained by Along-Strike Variation of Structural Geometry, Exhumation History, and Foreland Sedimentation. Earth-Science Rev. 76, 1-131. doi:10. 1016/j.earscirev.2005.05.004

Yin, A., Dang, Y. Q., Wang, L. C., Jiang, W. M., Zhou, S. P., Chen, X. H., et al. (2008a). Cenozoic Tectonic Evolution of Qaidam basin and its Surrounding Regions (Part 1): The Southern Qilian Shan-Nan Shan Thrust Belt and Northern Qaidam basin. Geol. Soc. America Bull. 120, 813-846. doi:10.1130/ b26180.1

Yin, A., Dang, Y. Q., Zhang, M., Chen, X. H., and McRivette, M. W. (2008b). Cenozoic Tectonic Evolution of the Qaidam basin and its Surrounding Regions (Part 3): Structural Geology, Sedimentation, and Regional Tectonic Reconstruction. Geol. Soc. America Bull. 120 (7-8), 847-876. doi:10.1130/ b26232.1

Yin, A., and Harrison, T. M. (2000). Geologic Evolution of the Himalayan-Tibetan Orogen. Annu. Rev. Earth Planet. Sci. 28, 211-280. doi:10.1146/annurev.earth. 28.1.211

Yin, A. (2000). Mode of Cenozoic East-West Extension in Tibet Suggesting a Common Origin of Rifts in Asia during the Indo-Asian Collision. J. Geophys. Res. 105, 21745-21759. doi:10.1029/2000jb900168

Yu, J., Pang, J., Wang, Y., Zheng, D., Liu, C., Wang, W., et al. (2019). MidMiocene Uplift of the Northern Qilian Shan as a Result of the Northward Growth of the Northern Tibetan Plateau. Geosphere 15, 423-432. doi:10. 1130/ges01520.1

Yuan, D. Y., Ge, W. P., Chen, Z. W., Li, C. Y., Wang, Z. C., Zhang, H. P., et al. (2013). The Growth of Northeastern Tibet and its Relevance to Large-Scale continental Geodynamics: A Review of Recent Studies. Tectonics 32, 1358-1370. doi:10.1002/tect.20081
Zhang, P., Shen, Z., Wang, M., Gan, W., Bürgmann, R., Molnar, P., et al. (2004) Continuous Deformation of the Tibetan Plateau from Global Positioning System Data. Geology 32, 809-812. doi:10.1130/g20554.1

Zheng, D., Clark, M. K., Zhang, P., Zheng, W., and Farley, K. A. (2010). Erosion, Fault Initiation and Topographic Growth of the North Qilian Shan (Northern Tibetan Plateau). Geosphere 6, 937-941. doi:10.1130/ges00523.1

Zheng, W., Zhang, P., Ge, W., Molnar, P., Zhang, H., Yuan, D., et al. (2013). Late Quaternary Slip Rate of the South Heli Shan Fault (Northern Hexi Corridor, NW China) and its Implications for Northeastward Growth of the Tibetan Plateau. Tectonics 32, 271-293. doi:10.1002/tect.20022

Zhong, D., and Ding, L. (1996). Discussion on the Uplift Process and Mechanism of the Qinghai-Tibet Plateau. Sci. China (Earth Sci. 26, 289-295. (in Chinese).

Zhou, J., Wang, J., An, Y., Spurlin, M. S., and Horton, B. K. (2002). Depositional Patterns and Tectonic Setting of Early Tertiary Basins in the NE Margin of the Tibetan Plateau: A Case Study of the Nangqian and Xialaxiu Basins (In Chinese). Acta Sed Sin 20, 85-91.

Zuza, A. V., Cheng, X., and Yin, A. (2016). Testing Models of Tibetan Plateau Formation with Cenozoic Shortening Estimates across the Qilian Shan-Nan Shan Thrust belt. Geosphere 12, 501-532. doi:10.1130/ges01254.1

Zuza, A. V., Gavillot, Y., Haproff, P. J., and Wu, C. (2020). Kinematic Evolution of a continental Collision: Constraining the Himalayan-Tibetan Orogen via Bulk Strain Rates. Tectonophysics 797. doi:10.1016/j.tecto.2020.228642

Zuza, A. V., Wu, C., Reith, R. C., Yin, A., Li, J., Zhang, J., et al. (2018a). Tectonic Evolution of the Qilian Shan: An Early Paleozoic Orogen Reactivated in the Cenozoic. Geol. Soc. Am. Bull. 130, 881-925. doi:10.1130/b31721.1

Zuza, A. V., Wu, C., Wang, Z., Levy, D. A., Li, B., Xiong, X., et al. (2019). Underthrusting and Duplexing beneath the Northern Tibetan Plateau and the Evolution of the Himalayan-Tibetan Orogen. Lithosphere 11, 209-231. doi:10. $1130 / 11042.1$

Conflict of Interest: The authors declare that the research was conducted in the absence of any commercial or financial relationships that could be construed as a potential conflict of interest.

Publisher's Note: All claims expressed in this article are solely those of the authors and do not necessarily represent those of their affiliated organizations, or those of the publisher, the editors and the reviewers. Any product that may be evaluated in this article, or claim that may be made by its manufacturer, is not guaranteed or endorsed by the publisher.

Copyright (c) 2022 Jia, Zheng, Zhang, Wei, Liang, Feng, Zhu, Tang and Wang. This is an open-access article distributed under the terms of the Creative Commons Attribution License (CC BY). The use, distribution or reproduction in other forums is permitted, provided the original author(s) and the copyright owner(s) are credited and that the original publication in this journal is cited, in accordance with accepted academic practice. No use, distribution or reproduction is permitted which does not comply with these terms. 